\title{
Systematic Review \\ Prevalence of Nasopharyngeal Carcinoma in Patients with Dermatomyositis: A Systematic Review and Meta-Analysis
}

\author{
Ahmad Adebayo Irekeola 1,2 1 , Rafidah Hanim Shueb 1,3,*iD, Engku Nur Syafirah E. A. R. 1, Yusuf Wada 1,4, \\ Zaidah Abdul Rahman 1,5, Suhana Ahmad ${ }^{6}$, Rohimah Mohamud ${ }^{6}$ (D), Norhafiza Mat Lazim ${ }^{7}$ (D) and \\ Chan Yean Yean ${ }^{1}$
}

check for updates

Citation: Irekeola, A.A.; Shueb, R.H.; E. A. R., E.N.S.; Wada, Y.; Abdul Rahman, Z.; Ahmad, S.; Mohamud, R.; Mat Lazim, N.; Yean, C.Y. Prevalence of Nasopharyngeal Carcinoma in Patients with Dermatomyositis: A Systematic Review and Meta-Analysis. Cancers 2021, 13, 1886. https://doi.org/ $10.3390 /$ cancers13081886

Academic Editor: Samuel C. Mok

Received: 1 February 2021

Accepted: 3 April 2021

Published: 14 April 2021

Publisher's Note: MDPI stays neutral with regard to jurisdictional claims in published maps and institutional affiliations.

Copyright: (c) 2021 by the authors. Licensee MDPI, Basel, Switzerland. This article is an open access article distributed under the terms and conditions of the Creative Commons Attribution (CC BY) license (https:// creativecommons.org/licenses/by/ $4.0 /)$.
1 Department of Medical Microbiology and Parasitology, School of Medical Sciences, Health Campus, Universiti Sains Malaysia, Kubang Kerian 16150, Kelantan, Malaysia; profahmad007@yahoo.com (A.A.I.); engkunursyafirah@student.usm.my (E.N.S.E.A.R.); wadayusuf@student.usm.my (Y.W.); drzaidah@usm.my (Z.A.R.); yychan@usm.my (C.Y.Y.)

2 Microbiology Unit, Department of Biological Sciences, College of Natural and Applied Sciences, Summit University Offa, Offa PMB 4412, Nigeria

3 Institute for Research in Molecular Medicine (INFORMM), Universiti Sains Malaysia, Kubang Kerian 16150, Kelantan, Malaysia

4 Department of Zoology, Faculty of Life Sciences, Ahmadu Bello University, Zaria 810211, Nigeria

5 Hospital Universiti Sains Malaysia, Universiti Sains Malaysia, Kubang Kerian 16150, Kelantan, Malaysia

6 Department of Immunology, School of Medical Sciences, Health Campus, Universiti Sains Malaysia,

Kubang Kerian 16150, Kelantan, Malaysia; suhanaahmad@usm.my (S.A.); rohimahm@usm.my (R.M.)

7 Department of Otorhinolaryngology-Head and Neck Surgery, School of Medical Sciences, Health Campus, Universiti Sains Malaysia, Kubang Kerian 16150, Kelantan, Malaysia; norhafiza@usm.my

* Correspondence: hanimshueb@gmail.com

Simple Summary: This first systematic review and meta-analysis on the prevalence of nasopharyngeal carcinoma in patients suffering dermatomyositis was necessitated by the absence of a true and reliable prevalence estimate necessary to adequately inform medical preparedness and decisions. Following a careful review of literature and data analyses, a prevalence of $3.3 \%$ was found. It is hoped that a clear knowledge of the actual prevalence of nasopharyngeal carcinoma in dermatomyositis patients would not only help sensitize clinicians and patients about the frequency of these disease conditions but would also enhance the adoption of precautions essential to mitigate their co-occurrence in patients.

Abstract: For more than 50 years, nasopharyngeal carcinoma (NPC) has been associated with dermatomyositis (DM), a rare idiopathic inflammatory disorder that mainly affects the skin and muscles. Although the association between these rare diseases is well-documented, the actual prevalence of NPC in DM patients remains unknown. Here, a systematic review and meta-analysis of published data was conducted in accordance with the guidelines of Preferred Reporting Items for Systematic Reviews and Meta-Analysis (PRISMA). Electronic databases including PubMed, Scopus, ScienceDirect, and Google Scholar were searched without year or language restrictions for studies reporting the occurrence of NPC in DM patients. The study protocol was lodged with PROSPERO (CRD42021225335). A total of 95 studies covering 303 cases of NPC among 16,010 DM patients was included. Summary estimates were calculated using the random-effects model. The pooled prevalence of NPC in DM was 3.3\% (95\% CI, 2.5-4.3). When stratified according to study location, higher prevalence estimates were obtained for Hong Kong (36.5\%), Malaysia (27.7\%), and Singapore $(11.9 \%)$. There was a predominance of cases among male DM patients compared with females, and most patients were aged 40 and above. Many of the NPC cases were found to be diagnosed after the diagnosis of DM. It is therefore pertinent to screen for NPC in DM patients, especially among older DM patients in the Asian region.

Keywords: nasopharyngeal carcinoma; nasopharyngeal neoplasm; NPC; dermatomyositis; dermatopolymyositis 


\section{Introduction}

Nasopharyngeal carcinoma (NPC) is a rare, malignant, non-lymphomatous, squamouscell carcinoma arising from the epithelial lining of the nasopharynx [1,2]. The neoplasm is highly associated with latent infection of Epstein-Barr virus (EBV), an organism present in about $95 \%$ of the total population [2,3]. Although the occurrence of this type of tumor among patients had been documented prior to 1901 [4], one of the early most exhaustive studies describing the clinicopathological characteristics of NPC drawn from 114 patients in Hong Kong was published in 1941 [5]. Many reports involving a large number of NPC patients have now been recorded. Although the disease is infrequent in many countries, it poses a major health challenge in Southeast Asia, Southern China, the Arctic, North Africa and the Middle East [6].

Nonspecific epistaxis, audiologic symptoms, unilateral nasal obstruction to cranial nerve palsies and nodal metastasis in the neck region often characterize the clinical presentation of NPC $[7,8]$. To date, the precise cause of the disease remains unclear. However, an array of risk factors has been described including ethnicity, hereditary trends, dietary habits, tobacco smoking and infection with EBV [2,9].

The association of NPC with paraneoplastic syndromes is well established [10]. In this review, we focus on dermatomyositis (DM) due to the increasing reports of identified cases. $\mathrm{DM}$ is an uncommon idiopathic inflammatory disorder principally affecting the skin and muscles [11]. Its pathophysiology is not well understood. Patients typically present with cutaneous disease accompanied or briefly followed by proximal muscle weakness [11]. The seminal study reporting the association of NPC with DM was published in 1969 [12]. Since then, patients with DM have been closely observed for potential underlying malignancies, and a myriad of case reports and cases series have been described in the literature. NPC can precede, follow or be concurrent to the diagnosis of DM, indicating that one disease condition could be a risk for the other. Further, it is tempting to surmise that NPC patients have a higher tendency to develop DM.

It has been suggested that patients with malignancy-associated myopathies are more resistant to treatment compared with those without malignancy [13,14]. An unfavorable prognosis may also ensue when DM is associated with NPC. Many researchers thus recommend that patients with DM be screened for NPC [15-18]. Inarguably, an understanding of the prevalence of NPC in DM would help inform medical decisions. Although several isolated reports of the occurrence of NPC in DM patients abound, the true prevalence is yet unknown. Here, we present a first report of the actual prevalence of NPC in DM by pooling available published data using a meta-analytical approach.

\section{Materials and Methods}

A systematic review and meta-analysis of published articles was conducted according to the guidelines of the Preferred Reporting Items for Systematic Reviews and MetaAnalyses (PRISMA) [19]. The study protocol for this review was registered with PROSPERO (registration number: CRD42021225335).

\subsection{Literature Search and Selection Criteria}

Four electronic databases (PubMed, Scopus, ScienceDirect, and Google Scholar) were searched using a combination of relevant keywords: "nasopharyngeal carcinoma", "NPC", "nasopharyngeal neoplasm", "nasopharyngeal cancer", "malignancy", "cancer", "dermatomyositis", "dermatopolymyositis" and "myositis". Full details of the search strategies employed for all the searched databases are available as a Supplementary Document (File S1). The search was elaborate: filter for language, country, study design or year of publication was not applied. The initial search was done on 9 December 2020. The updated and final search returning a total of 4870 articles (Figure 1) was conducted on 11 March 2021. All references were exported to EndNote X8 software and were followed by duplicate removal. 
Studies that investigated the occurrence of NPC and/or other cancers in patients suffering DM were considered for inclusion. We excluded (1) opinions, reviews, letters, book chapters, editorials and case reports; (2) studies that reported the occurrence of NPC in conditions other than DM; (3) studies whose NPC screening status were unclear or that did not include NPC among the cancers examined in DM patients and (4) articles whose full text could not be accessed. To ensure an exhaustive search, we perused and reviewed the references of the included studies.

All authors participated in delineating the article screening, selection, and assessment criteria. Two authors (A.A.I. and E.N.S.E.A.R.) independently screened the articles based on title and abstract. This was followed by the assessment of the full texts. Disagreements in the screening process were resolved by discussion including other authors.
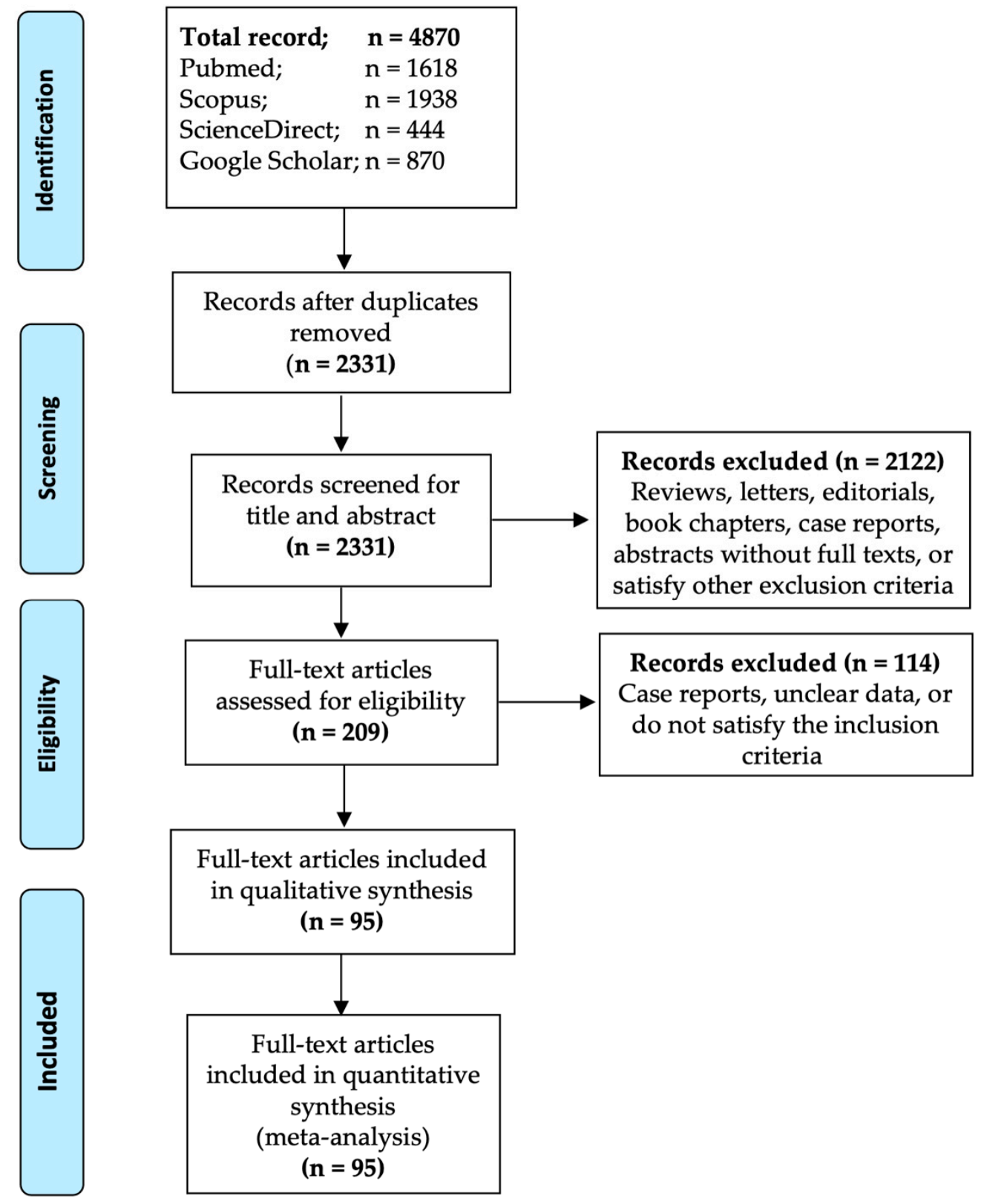

Full-text articles included in qualitative synthesis ( $n=95$ )

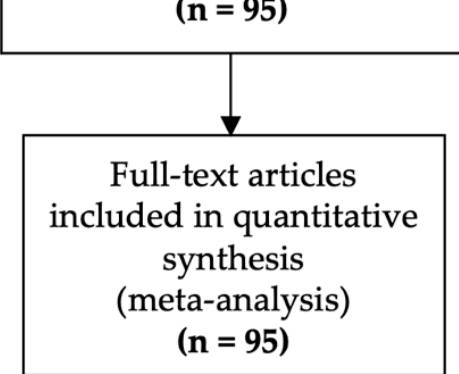

Figure 1. Summary of article identification and selection process. 


\subsection{Data Extraction and Quality Assessment}

Data extraction was done using a predefined Excel spreadsheet. Three authors (A.A.I., S.A. and E.N.S.E.A.R.) independently extracted information regarding the study ID, year of publication, study period, study design, study location, number of patients involved, including their age and sex, number of NPC cases reported as well as the age and sex of the patients involved, and the period NPC was diagnosed among the cases.

The methodological quality of the included studies was assessed independently by two authors (A.A.I. and Y.W.) using the Joanna Briggs Institute (JBI) critical appraisal checklist for prevalence data [20] (File S2). A score of 1 for "yes" and 0 for other parameters were assigned to attain a total quality score that ranged from 0 to 9 . Studies with an overall score of 7-9 were considered to be of sufficient quality.

\subsection{Data Synthesis and Analysis}

Data analysis was done using OpenMeta Analyst and meta (version 4.15-1) and metafor (version 2.4-0) packages of $\mathrm{R}$ (version 4.0.3) and RStudio (version 1.3.1093) [21]. The pooled prevalence of NPC in patients with DM was calculated, and subgroup analysis was done according to the location, geographical region and period of study. Randomeffect model using the DerSimonian-Laird method of meta-analysis was used to derive the pooled estimates of the reported NPC cases. In addition to assessing study quality, potential publication bias was investigated by generating a funnel plot. The asymmetry of the plot was further assessed using Egger's regression test [22]. The heterogeneities of study-level estimates were evaluated by Cochran's $Q$ test and quantified using $I^{2}$ statistics. $I^{2}$ values of $25 \%, 50 \%$, and $75 \%$ were considered low, moderate, and high heterogeneity, respectively [23]. Subgroup meta-analysis was used to analyze sources of heterogeneity. A sensitivity test was conducted using the leave-one-out analysis and the exclusion of studies with few participants. For all tests, $p$-value of $<0.001$ was considered to be statistically significant.

\section{Results}

\subsection{Study Selection}

The study selection process for this study is presented in Figure 1. Briefly, our search of four electronic databases returned 4870 records. After removing duplicates and studies satisfying our exclusion criteria, the full texts of 209 studies were evaluated for eligibility. Finally, 95 studies were considered fully eligible and were included in the qualitative and quantitative analyses.

\subsection{Characteristics of the Eligible Studies}

The studies included in this meta-analysis were principally retrospective cohort studies of DM patients at hospital settings, with study periods ranging from 2 to 47 years. Female patients constituted the majority of the enrolled participants, and many of the studies were from the Asian region. Detailed characteristics of the eligible studies are presented in Table 1. 
Table 1. Major characteristics of the included studies reporting the occurrence of NPC in dermatomyositis patients.

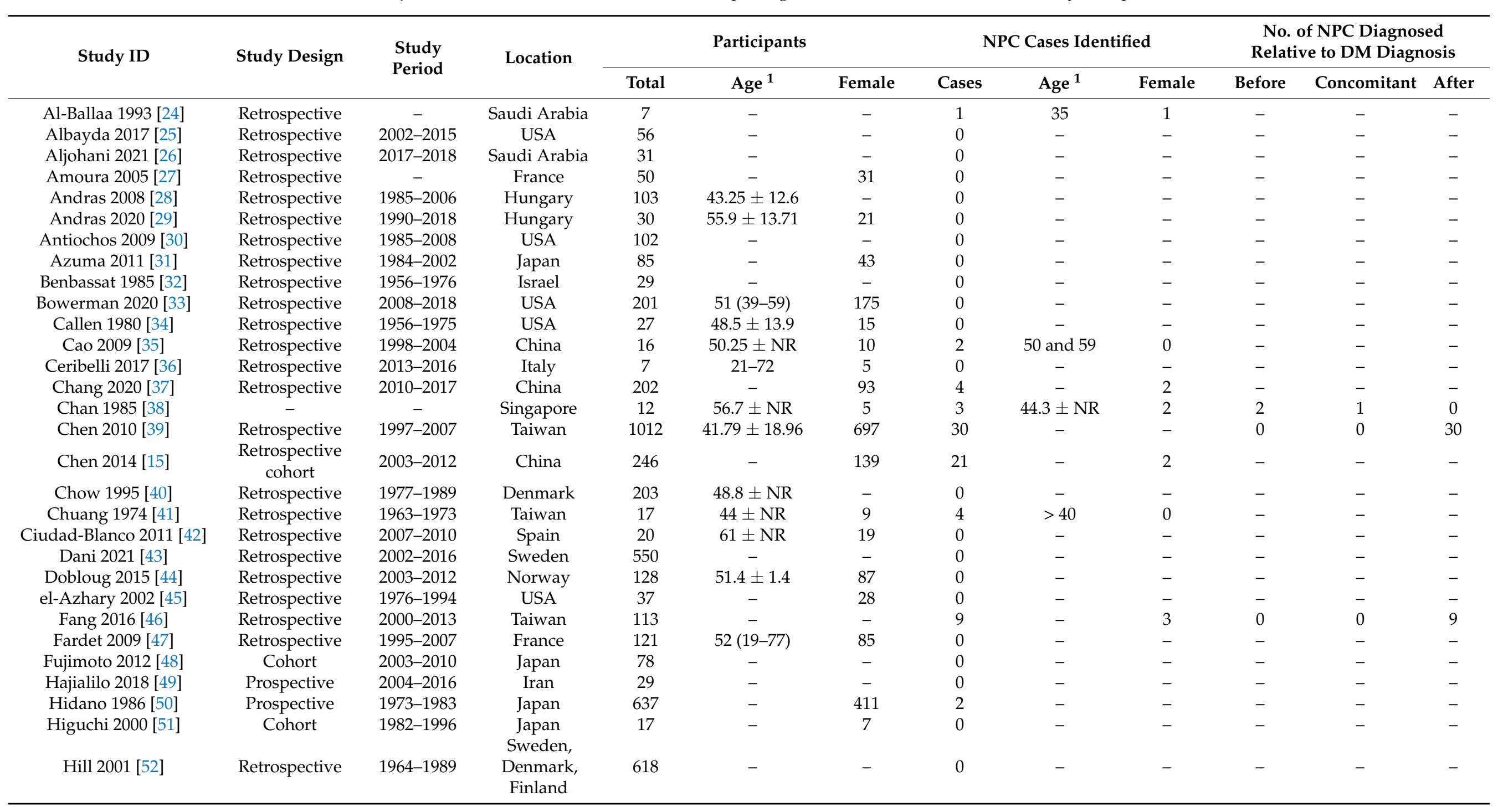


Table 1. Cont.

\begin{tabular}{|c|c|c|c|c|c|c|c|c|c|c|c|c|}
\hline \multirow[t]{2}{*}{ Study ID } & \multirow[t]{2}{*}{ Study Design } & \multirow{2}{*}{$\begin{array}{l}\text { Study } \\
\text { Period }\end{array}$} & \multirow[t]{2}{*}{ Location } & \multicolumn{3}{|c|}{ Participants } & \multicolumn{3}{|c|}{ NPC Cases Identified } & \multicolumn{3}{|c|}{$\begin{array}{l}\text { No. of NPC Diagnosed } \\
\text { Relative to DM Diagnosis }\end{array}$} \\
\hline & & & & Total & Age $^{1}$ & Female & Cases & Age $^{1}$ & Female & Before & Concomitant & After \\
\hline Hsu 2021 [53] & Retrospective & $2001-2019$ & Taiwan & 1032 & - & - & 14 & - & 5 & 4 & 0 & 10 \\
\hline Huang 2009 [14] & Retrospective & $2000-2005$ & Taiwan & 1059 & $42.4 \pm 19.0$ & 730 & 40 & - & 14 & 10 & 0 & 30 \\
\hline Hunger 2001 [54] & Retrospective & $1991-1998$ & Switzerland & 23 & $48 \pm \mathrm{NR}$ & 14 & 1 & 66 & 0 & 0 & 0 & 1 \\
\hline Ibanez 2016 [55] & Retrospective & 2010-2015 & Argentina & 16 & $33-76$ & 12 & 0 & - & - & - & - & - \\
\hline Ichimura 2012 [56] & Retrospective & $2003-2010$ & Japan & 7 & $23-68$ & 1 & 0 & - & - & - & - & - \\
\hline Ikeda 2011 [57] & Cohort & $2000-2009$ & Japan & 55 & $55.1 \pm 14.2$ & 39 & 0 & - & - & - & - & - \\
\hline Isik 2014 [59] & Retrospective & $2000-2011$ & Ankara & 22 & - & - & 1 & - & - & - & - & - \\
\hline Kaji 2007 [60] & Cohort & - & Japan & 52 & $55 \pm \mathrm{NR}$ & 12 & 0 & - & - & - & - & - \\
\hline Kang 2016 [61] & Retrospective & - & South Korea & 192 & - & - & 0 & - & - & - & - & - \\
\hline Kannan 2013 [62] & Retrospective & $2000-2009$ & India & 63 & - & 40 & 0 & - & - & - & - & - \\
\hline Koh 1993 [63] & Retrospective & 1986-1991 & Singapore & 40 & $52.3 \pm \mathrm{NR}$ & 22 & 2 & - & 0 & - & - & - \\
\hline Kubo 2000 [64] & Cohort & - & Japan & 37 & - & - & 0 & - & - & - & - & - \\
\hline Kuo 2011 [16] & Retrospective & $2003-2007$ & Taiwan & 803 & $44.0 \pm 18.3$ & 555 & 29 & - & 10 & - & - & - \\
\hline Lakhanpal 1986 [65] & Retrospective & $1965-1974$ & USA & 50 & - & 41 & 0 & - & - & - & - & - \\
\hline Lam 1999 [66] & $\begin{array}{c}\text { Prospective } \\
\text { cohort }\end{array}$ & 1988-1996 & Hong Kong & 10 & - & 2 & 3 & - & - & - & - & - \\
\hline Leatham 2018 [67] & Retrospective & 1983-2013 & USA & 400 & $51.9(8-84)$ & 323 & 1 & - & - & 0 & 0 & 1 \\
\hline Lee 2006 [68] & Retrospective & $1995-2003$ & South Korea & 16 & - & 12 & 1 & 51 & 0 & 0 & 0 & 1 \\
\hline Leow 1997 [17] & Retrospective & 1989-1994 & Singapore & 38 & $53.6 \pm \mathrm{NR}$ & 21 & 5 & $>41$ & - & 2 & 1 & 1 \\
\hline Li 2020 [69] & Cohort & $2010-2015$ & China & 75 & $52.89 \pm 10.14$ & 39 & 4 & $30-61$ & 2 & 0 & 0 & 4 \\
\hline $\operatorname{Lim} 2018$ [70] & Retrospective & $1998-2014$ & Taiwan & 98 & - & - & 1 & 55 & 0 & - & - & 1 \\
\hline Liu 2010 [71] & $\begin{array}{l}\text { Retrospective } \\
\text { cohort }\end{array}$ & 1996-2006 & Singapore & 68 & $50 \pm \mathrm{NR}$ & 47 & 7 & $49.5 \pm \mathrm{NR}$ & 3 & 1 & 3 & 3 \\
\hline Liu 2018 [72] & Retrospective & 1997-2016 & China & 239 & $\begin{array}{c}58 \\
(53.0-67.75)\end{array}$ & 161 & 4 & - & 1 & - & - & - \\
\hline Maliha 2019 [73] & Cohort & 2005-2018 & Canada & 31 & $54 \pm 17$ & 24 & 0 & - & - & - & - & - \\
\hline Manchul 1985 [74] & Retrospective & 1965-1980 & Canada & 31 & - & - & 1 & 58 & 1 & 0 & 1 & 0 \\
\hline Maravi 2020 [75] & Retrospective & 2016-2017 & Chile & 15 & $53 \pm \mathrm{NR}$ & 12 & 0 & - & - & - & - & - \\
\hline Marie 1999 [76] & Retrospective & 1983-1997 & France & 39 & - & - & 0 & - & - & - & - & - \\
\hline Masiak 2016 [77] & Retrospective & $2014-2016$ & Poland & 6 & $58.7 \pm \mathrm{NR}$ & 4 & 0 & - & - & - & - & - \\
\hline Mebazaa 2003 [78] & Retrospective & $1982-2000$ & Tunisia & 130 & $49.6 \pm \mathrm{NR}$ & - & 5 & $16-65$ & 2 & 0 & 2 & 3 \\
\hline
\end{tabular}


Table 1. Cont

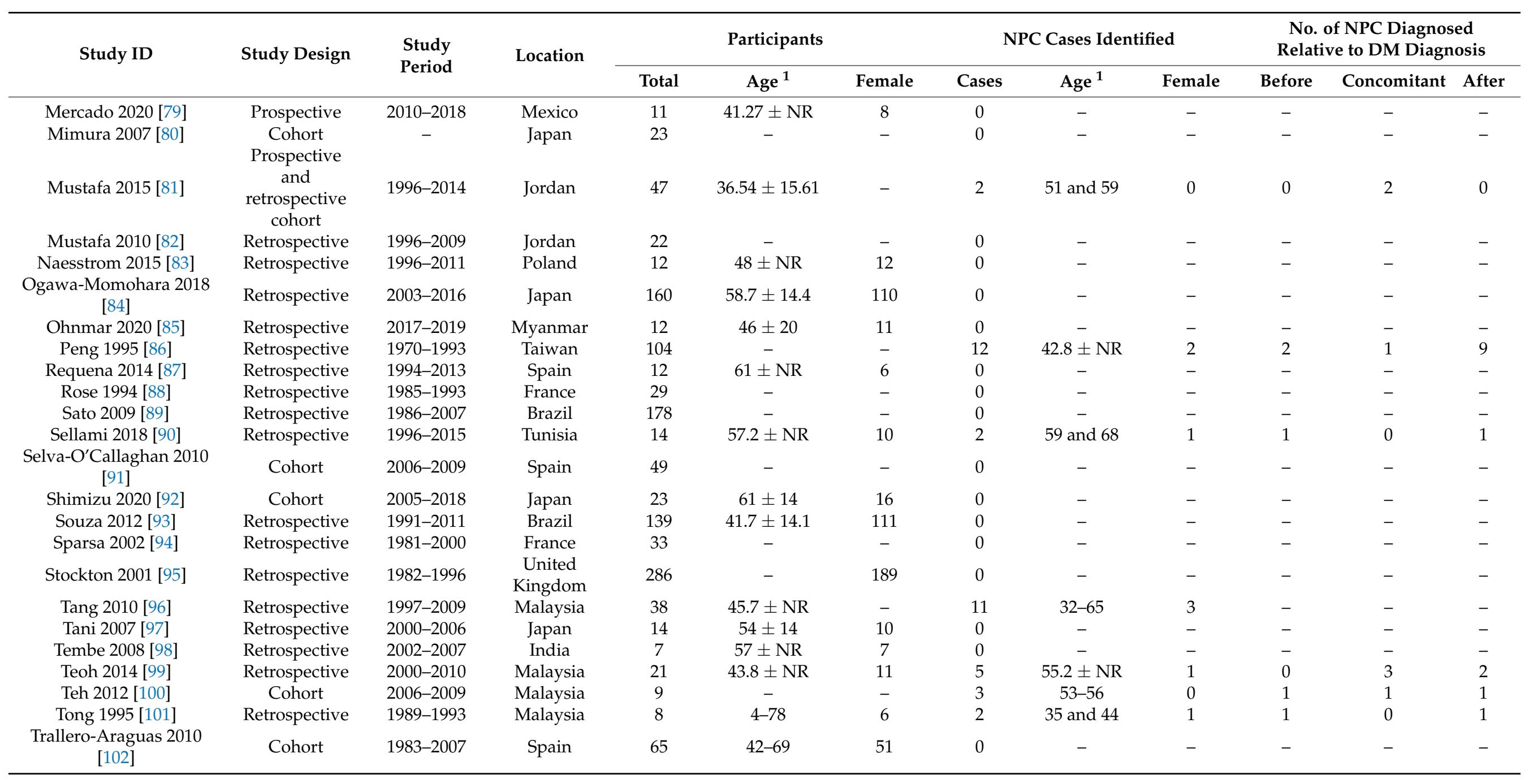


Table 1. Cont.

\begin{tabular}{|c|c|c|c|c|c|c|c|c|c|c|c|c|}
\hline \multirow[t]{2}{*}{ Study ID } & \multirow[t]{2}{*}{ Study Design } & \multirow{2}{*}{$\begin{array}{l}\text { Study } \\
\text { Period }\end{array}$} & \multirow[t]{2}{*}{ Location } & \multicolumn{3}{|c|}{ Participants } & \multicolumn{3}{|c|}{ NPC Cases Identified } & \multicolumn{3}{|c|}{$\begin{array}{c}\text { No. of NPC Diagnosed } \\
\text { Relative to DM Diagnosis }\end{array}$} \\
\hline & & & & Total & Age $^{1}$ & Female & Cases & Age $^{1}$ & Female & Before & Concomitant & After \\
\hline Trallero-Araguas 2016 & Retrospective & - & Spain & 62 & - & - & 0 & - & - & - & - & - \\
\hline Travassos 2013 [104] & Retrospective & $1965-2011$ & Portugal & 33 & $56 \pm \mathrm{NR}$ & 19 & 0 & - & - & - & - & - \\
\hline Tripathi 2020 [105] & Retrospective & 2009-2015 & USA & 4278 & - & 3042 & 0 & - & - & - & - & - \\
\hline Troyanov 2014 [106] & Prospective & 1967-2001 & France & 44 & - & - & 0 & - & - & - & - & - \\
\hline $\begin{array}{c}\text { Ueda-Hayakawa } 2019 \\
\text { [107] }\end{array}$ & Cohort & - & Japan & 6 & $54 \pm \mathrm{NR}$ & 5 & 0 & - & - & - & - & - \\
\hline Ueki 2019 [108] & Retrospective & 1990-2016 & Japan & 24 & - & - & 0 & - & - & - & - & - \\
\hline Uthman 1996 [109] & Retrospective & 1980-1992 & France & 9 & $40.2 \pm \mathrm{NR}$ & 5 & 0 & - & - & - & - & - \\
\hline $\begin{array}{c}\text { VanDeVlekkert } 2014 \\
\text { [110] }\end{array}$ & Prospective & - & $\begin{array}{l}\text { The } \\
\text { Netherlands }\end{array}$ & 24 & - & - & 0 & - & - & - & - & - \\
\hline Wakata 2002 [111] & Retrospective & 1969-1999 & Japan & 28 & $19-74$ & 22 & 0 & - & - & - & - & - \\
\hline Wong 1969 [12] & Cohort & 1963-1968 & Hong Kong & 23 & $21-70$ & 8 & 9 & - & - & - & - & - \\
\hline Yosipovitch 2012 [112] & $\begin{array}{l}\text { Prospective } \\
\text { cohort }\end{array}$ & 2003-2006 & Singapore & 15 & $50 \pm 17$ & 10 & 2 & - & - & 0 & 0 & 2 \\
\hline Zhang 2009 [113] & Retrospective & 1974-2008 & China & 678 & - & 423 & 59 & - & - & - & - & - \\
\hline
\end{tabular}

${ }^{1}$ Age is presented in years [(mean $\pm \mathrm{SD} /$ median(range/IQR)/range)]; No., number; NPC, nasopharyngeal carcinoma; DM, dermatomyositis; NR, not reported. 


\subsection{Prevalence of NPC in Dermatomyositis}

The 95 studies included in this meta-analysis involved a total of 303 NPC cases among 16,010 DM patients. Using the random-effect model, the pooled prevalence of NPC in DM patients was estimated at 3.3\% (95\% CI, 2.5-4.3) (Figure 2). A relatively high heterogeneity was observed from the statistics $\left(I^{2}=74.03 \% ; \mathrm{Q}=361.951 ; p<0.001\right)$.

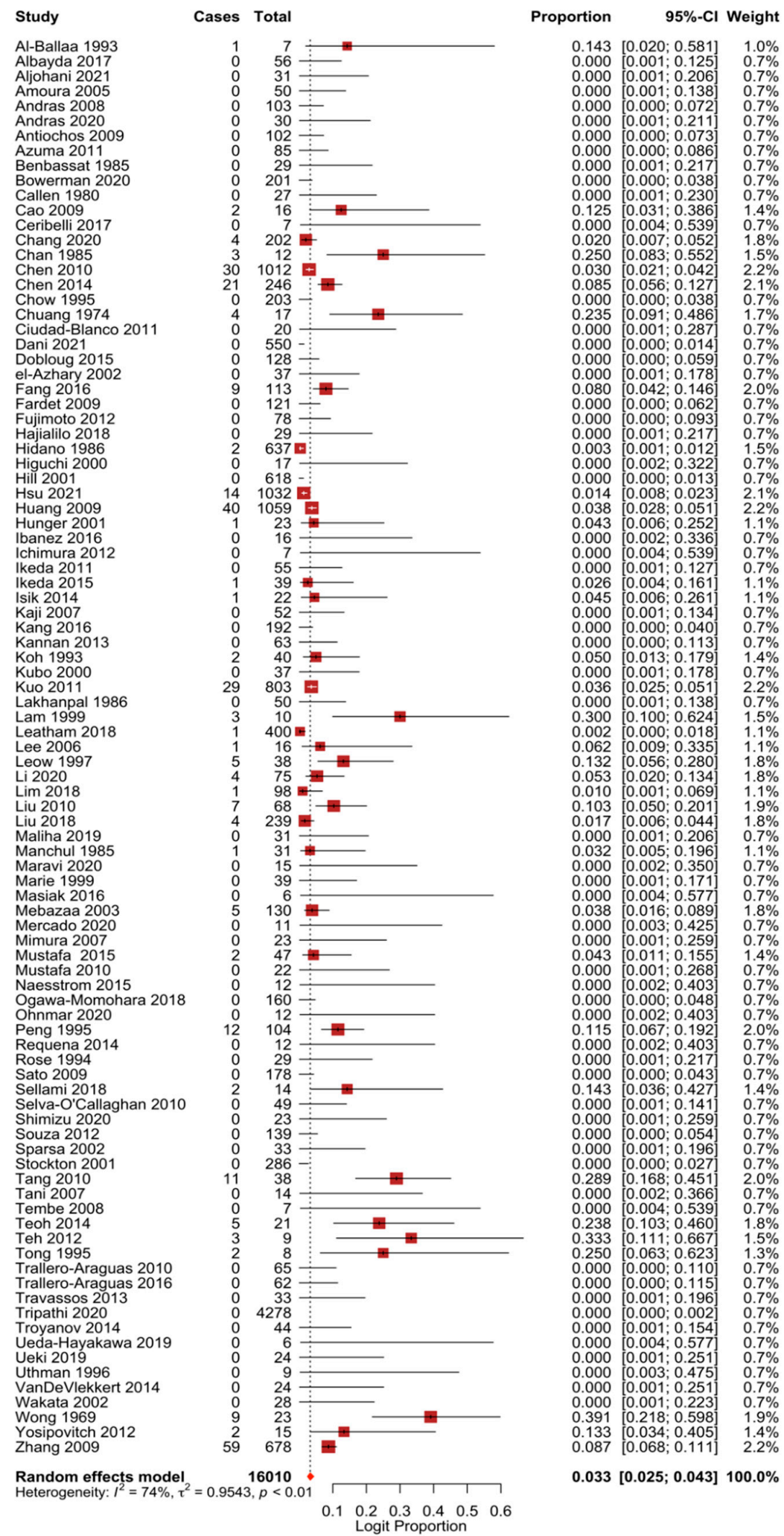

Figure 2. Forest plot of the pooled prevalence of NPC in dermatomyositis patients. 


\subsection{Prevalence of NPC in Dermatomyositis Stratified by Study Location and Region}

A subgroup meta-analysis was conducted to assess the prevalence of NPC in DM patients from different locations and regions of the globe. From the included studies, data were available for thirty-three locations with the majority of studies from Japan $(n=16)$ (Table 2; Figure S1A).

The highest pooled prevalence estimate of $36.5 \%$ (95\% CI, 22.0-53.9) was observed for Hong Kong, while the least estimate of $0.1 \%$ (95\% CI, 0.0-1.4) was in Sweden (Table 2; Figure S1A). Studies from India and Taiwan demonstrated a high heterogeneity $\left(I^{2}=90.7 \%\right.$ and $I^{2}=86.61 \%$, respectively; $p<0.001$ ) and may have contributed to the overall heterogeneity observed.

At the regional level, Asia was the most represented (46 studies) (Table 2; Figure S1B). The highest pooled prevalence estimate of $6.7 \%$ (95\% CI, 1.8-22.1) was obtained for Africa, while the lowest prevalence of NPC in DM was in North America (0.7\%; 95\% CI, 0.3-1.8). Studies from Asia demonstrated a high heterogeneity (82.01\%).

A higher pooled prevalence $(5.2 \%)$ was observed in studies whose duration was ten years or below (Table 2; Figure S1C).

Table 2. Subgroup analysis. Prevalence of NPC in dermatomyositis patients stratified by study location, geographical region and period of study.

\begin{tabular}{|c|c|c|c|c|c|c|c|}
\hline \multirow{2}{*}{ Subgroup } & \multirow{2}{*}{ No of Studies } & \multirow{2}{*}{$\begin{array}{c}\text { Prevalence } \\
(\%)\end{array}$} & \multirow{2}{*}{$95 \%$ CI } & \multirow{2}{*}{$I^{2}(\%)$} & \multirow{2}{*}{$\mathbf{Q}$} & \multicolumn{2}{|c|}{ Heterogeneity Tes } \\
\hline & & & & & & DF & $p$ \\
\hline Location & & & & & & & \\
\hline Saudi Arabia & 2 & 5.8 & $0.6-37.6$ & 42.15 & 1.729 & 1 & 0.189 \\
\hline USA & 8 & 0.4 & $0.1-1.1$ & 23.45 & 9.144 & 7 & 0.242 \\
\hline France & 7 & 1.3 & $0.5-3.7$ & 0 & 1.678 & 6 & 0.947 \\
\hline Hungary & 2 & 0.9 & $0.1-6.0$ & 0 & 0.369 & 1 & 0.543 \\
\hline Japan & 16 & 1.2 & $0.6-2.2$ & 0 & 10.017 & 15 & 0.819 \\
\hline Israel & 1 & 1.7 & $0.1-21.7$ & - & - & - & - \\
\hline China & 6 & 5.4 & $3.1-9.1$ & 75.01 & 20.004 & 5 & 0.001 \\
\hline Italy & 1 & 6.3 & $0.4-53.9$ & - & - & - & - \\
\hline Singapore & 5 & 11.9 & $7.7-17.9$ & 0 & 3.777 & 4 & 0.437 \\
\hline Taiwan & 8 & 4.6 & $2.8-7.4$ & 86.61 & 52.293 & 7 & $<0.001$ \\
\hline Denmark & 1 & 0.2 & $0.0-3.8$ & - & - & - & - \\
\hline Spain & 5 & 1.4 & $0.4-4.7$ & 0 & 1.070 & 4 & 0.899 \\
\hline Sweden & 1 & 0.1 & $0.0-1.4$ & - & - & - & - \\
\hline Norway & 1 & 0.4 & $0.0-5.9$ & - & - & - & - \\
\hline Iran & 1 & 1.7 & $0.1-21.7$ & - & - & - & - \\
\hline Switzerland & 1 & 4.3 & $0.6-25.2$ & - & - & - & - \\
\hline Argentina & 1 & 2.9 & $0.2-33.6$ & - & - & - & - \\
\hline Ankara & 1 & 4.5 & $0.6-26.1$ & - & - & - & - \\
\hline South Korea & 2 & 1.5 & $0.1-26.5$ & 70.83 & 3.428 & 1 & 0.064 \\
\hline India & 2 & 2.2 & $0.3-15.3$ & 90.7 & 1.100 & 1 & 0.294 \\
\hline Hong Kong & 2 & 36.5 & $22.0-53.9$ & 0 & 0.250 & 1 & 0.617 \\
\hline Canada & 2 & 2.5 & $0.5-11.6$ & 0 & 0.180 & 1 & 0.672 \\
\hline Chile & 1 & 3.1 & $0.2-35.0$ & - & - & - & - \\
\hline Poland & 2 & 5.2 & $0.7-29.3$ & 0 & 0.101 & 1 & 0.751 \\
\hline Tunisia & 2 & 6.7 & $1.8-22.1$ & 61.15 & 2.574 & 1 & 0.109 \\
\hline Mexico & 1 & 4.2 & $0.3-42.5$ & - & - & - & - \\
\hline Jordan & 2 & 3.7 & $1.1-12.0$ & 0 & 0.187 & 1 & 0.665 \\
\hline Myanmar & 1 & 3.8 & $0.2-40.3$ & - & - & - & - \\
\hline Brazil & 2 & 0.3 & $0.0-2.2$ & 0 & 0.015 & 1 & 0.902 \\
\hline United Kingdom & 1 & 0.2 & $0.0-2.7$ & - & - & - & - \\
\hline Malaysia & 4 & 27.7 & $18.8-38.9$ & 0 & 0.358 & 3 & 0.949 \\
\hline Portugal & 1 & 1.5 & $0.1-19.6$ & - & - & - & - \\
\hline The Netherlands & 1 & 2.0 & $0.1-25.1$ & - & - & - & - \\
\hline Overall & 94 & 3.4 & $2.6-4.5$ & 73.66 & 353.089 & 93 & $<0.001$ \\
\hline
\end{tabular}


Table 2. Cont

\begin{tabular}{|c|c|c|c|c|c|c|c|}
\hline \multirow{2}{*}{ Subgroup } & \multirow{2}{*}{ No of Studies } & \multirow{2}{*}{$\begin{array}{c}\text { Prevalence } \\
(\%)\end{array}$} & \multirow{2}{*}{$95 \%$ CI } & \multirow{2}{*}{$I^{2}(\%)$} & \multirow{2}{*}{$\mathbf{Q}$} & \multicolumn{2}{|c|}{ Heterogeneity Test } \\
\hline & & & & & & DF & $p$ \\
\hline \multicolumn{8}{|l|}{ Region } \\
\hline Middle East & 6 & 3.7 & $1.5-8.7$ & 0 & 3.076 & 5 & 0.688 \\
\hline North America & 11 & 0.7 & $0.3-1.8$ & 33.56 & 15.051 & 10 & 0.130 \\
\hline Europe & 25 & 1.1 & $0.7-1.9$ & 0 & 19.525 & 24 & 0.723 \\
\hline Asia & 47 & 5.7 & $4.1-7.9$ & 81.61 & 250.180 & 46 & $<0.001$ \\
\hline South America & 4 & 1.0 & $0.2-3.8$ & 0 & 2.592 & 3 & 0.459 \\
\hline Africa & 2 & 6.7 & $1.8-22.1$ & 61.15 & 2.574 & 1 & 0.109 \\
\hline Overall & 95 & 3.3 & $2.5-4.3$ & 74.03 & 361.951 & 94 & $<0.001$ \\
\hline \multicolumn{8}{|l|}{ Study period } \\
\hline More than 10 years & 50 & 2.3 & $1.5-3.4$ & 78.28 & 225.627 & 49 & $<0.001$ \\
\hline Ten years or less & 35 & 5.2 & $3.4-7.8$ & 70.75 & 116.256 & 34 & $<0.001$ \\
\hline Overall & 85 & 3.3 & $2.5-4.4$ & 75.45 & 342.171 & 84 & $<0.001$ \\
\hline
\end{tabular}

\subsection{Analyses of Sensitivity and Publication Bias}

First, the impact of small sample size was evaluated. Ten studies $[24,36,56,66,77,98$, $100,101,107,109]$ with sample sizes of 10 and below were excluded and the prevalence re-estimated. The resulting prevalence estimate was $2.8 \%$ (95\% CI, 2.1-3.7; $I^{2}=75.03$; $\mathrm{Q}=336.390 ; p<0.001$ ) (Figure S2A), indicating a slight decrease from the original prevalence of $3.3 \%$. Sensitivity was further assessed by removing one study at a time (i.e., leave-one-out analysis) using the random-effects model. A prevalence estimate of $3.1 \%$ (95\% CI, 2.4-4.2) was obtained when the study of Zhang 2009 [113] was removed. This represented the lowest estimate observed following the analysis (Figure S2B). On the other hand, the highest prevalence estimate of $3.5 \%(95 \% \mathrm{CI}, 2.6-4.5)$ was observed when the study of Tripathi 2020 [105] was removed. Overall, the NPC prevalence estimates were stable (Figure S2B).

The included studies were of good methodological quality (Table S1). A funnel plot was generated for all the included studies (Figure 3). A visual observation of the plot showed a relatively symmetrical plot with evidence of publication bias. In addition, Egger's regression test for funnel plot asymmetry revealed a significant $p$-value $(p=0.0008)$.

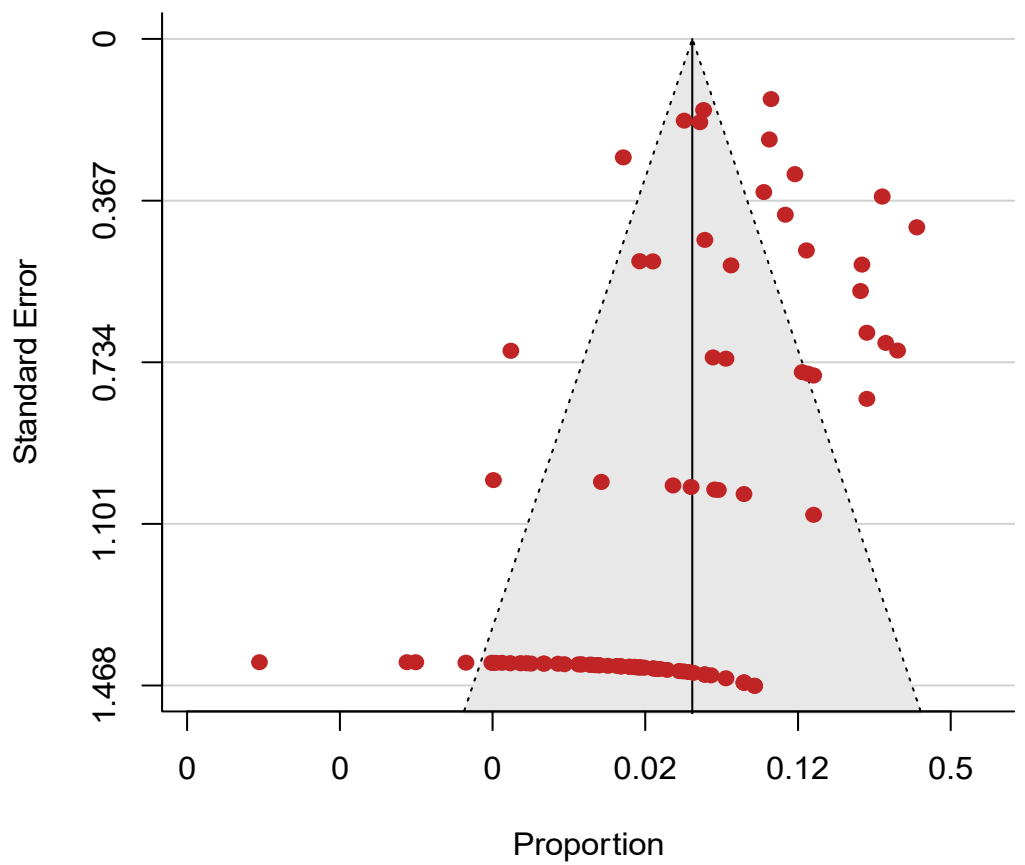

Figure 3. Funnel plot showing evidence of publication bias (Egger's test, $p=0.0008$ ). 


\section{Discussion}

Dermatomyositis (DM) has been associated with underlying malignancies for over a century. The association between DM and cancer was first suggested in 1916 by Stertz [114]. A wide range of malignancies including but not limited to NPC, adenocarcinoma of the lung, breast, pancreas, stomach, colon, and ovary have been described in relation to DM $[68,115]$. An underlying malignancy is believed to occur in about $15-24 \%$ of DM cases [15,115]. Although NPC is considered one of the most common malignancies associated with DM [39,116], the true prevalence of NPC in DM remains unknown as reported prevalence vary with studies. In this systematic review and meta-analysis, an attempt was made to harmonize the various studies reporting the occurrence of NPC in DM patients with the view to deriving a reliable prevalence estimate.

From a total of 2331 relevant articles screened, 95 eligible studies were analyzed. It is noteworthy that over 100 case reports presenting cases of patients with NPC and DM were identified in the course of this review. However, they were excluded since they do not meet the inclusion criteria of a prevalence study. The myriad of case reports encountered encompassed virtually all the regions of the globe. For example, in Europe, Botsios et al. [117] reported a clinical case of a Caucasian Italian patient. Further, in the United Kingdom, Mitra et al. [118] reported the first case of NPC in association with DM. Other similar cases included reports by Boussen et al., Ezejiofor et al. and Boussetta et al. [119-122] (Africa); Patel et al. [123] (North America); Bica et al. [124] (South America); Low et al. and Kabuto et al. [125,126] (Asia); and Vardi et al. [127] (Oceania). These are indications of the global existence of NPC in DM despite its rarity.

In this study, the prevalence of NPC in DM patients was found to be $3.3 \%$ with national estimates hovering between $0.1 \%$ and $36.5 \%$. There was a preponderance of studies from the Asian region; about $50 \%$ of the studies that contributed to the pooled prevalence estimate obtained were from the region. This could be linked to the fact that NPC is a disease prominent among the Asian population, particularly in Southeast Asia and Southern China [6]. The association of NPC and DM is not commonly reported in the Western population [128]. For instance, despite the identification of some malignancies, NPC was not reported in a pooled analysis of DM cases derived from published national data from Finland, Denmark, and Sweden [52]. Similarly, NPC was not identified in a 21year retrospective study of a Hungarian DM cohort [28]. The most common malignancies associated with DM in Western country cohorts appear to be lung, breast, ovarian and colorectal cancers $[30,52,95]$.

A close evaluation of the NPC cases analyzed revealed a predominance of male patients (Table 1). Although data on gender were unavailable for the majority of the NPC cases identified, the observed high prevalence of NPC among male DM patients highlights the potential role of gender in the disease condition. Previous studies have established male sex as a predictive factor associated with increased risk of malignancy in dermatomyositis/polymyositis patients [116]. This is in addition to other factors such as cutaneous vasculitis [54,129], cutaneous necrosis [47,130], dysphagia [31,131,132] and periungual erythema [47], among others. The ratio of males to females in the enrolled participants across the studies assessed (Table 1) did not seem to impact the low prevalence of NPC recorded in females, as a relatively high number of participants enrolled in many of the studies were females. Other population-based studies have found ovarian cancer as the most commonly associated malignancy in female DM patients [40,52,133].

Another crucial factor examined in this study was age. We found the majority of the enrolled participants to be adults, and mainly above 40 years, suggesting the predominance of NPC in adult DM. This was, however, expected, as older age had been recognized in many previous studies as a risk factor for malignancy in DM [76,134,135]. Juvenile DM, a childhood-type DM, is extremely uncommon. It affects only about two to four children per million [136]. The association of juvenile DM and malignancy is not well-established, and routine malignancy screening is seldom performed in affected individuals [15]. This perhaps warranted the exclusion of this group from the design of some studies. Never- 
theless, cases of juvenile DM were not entirely absent in this study. For example, Huang et al. [14] reported two cases of malignancy-associated DM out of 147 cases involving DM patients under 18 years. Although the comorbid malignancies were reticuloendothelial malignancies, it is noteworthy that both patients were females.

Given that NPC can occur before, after or concurrently with DM diagnosis, we attempted to evaluate the frequency of NPC diagnosis in relation to DM diagnosis among the included studies. Although this detail was inadequately reported (Table 1), studies for which data were available suggest that NPC occurs mostly after the diagnosis of DM, with the diagnosis of NPC ranging from a few weeks to several years after DM diagnosis. In the study conducted by Chen et al. [15], the highest risk of malignancy was found to be within the first year after DM diagnosis. A more detailed study is, however, required to support this assertion. Overall, it is pertinent to prioritize screening for malignancy in DM patients, and particularly NPC among DM patients in the Asian population.

This study has a number of strengths. A major strength is that, to our knowledge, it is the first systematic review and meta-analysis on the prevalence of NPC in DM. Further, a comprehensive search strategy was employed, and a large number of records were screened. In addition, the prevalence estimate obtained was quite stable as confirmed by the sensitivity tests conducted. Lastly, we believe that there is high confidence in the results obtained, since the included studies were of good methodological quality. However, this work is not without limitations, all of which are related to the status of the literature assessed. First, some of the studies included in the analyses were of small sample sizes. Furthermore, information regarding sex, age and period of NPC diagnosis, which are crucial to a comprehensive appraisal of the NPC cases identified, were not reported in some of the studies analyzed in this work.

\section{Conclusions}

In this systematic review and meta-analysis, which to our knowledge is the first report, the prevalence of NPC in DM patients was investigated. A pooled prevalence of $3.3 \%$ was derived from published studies from various parts of the world. Based on the findings from this study, screening for NPC in DM patients is highly recommended, particularly among older male DM patients in the Asian region.

Supplementary Materials: The following are available online at https:/ /www.mdpi.com/article/10 .3390 / cancers13081886/s1, Figure S1: Forest plot of the pooled prevalence of NPC in dermatomyositis patients stratified by study location, geographical region and period of study, Figure S2: Sensitivity tests, Table S1: Quality assessment of included studies, File S1: Search strategy, File S2: Joanna Briggs Institute (JBI) critical appraisal checklist for prevalence studies.

Author Contributions: Conceptualization, A.A.I. and R.H.S.; methodology, all authors; software, A.A.I., Y.W. and R.H.S.; data extraction, synthesis and interpretation, all authors; formal analysis, A.A.I.; writing —original draft preparation, A.A.I.; writing-review and editing, all authors. All authors have read and agreed to the published version of the manuscript.

Funding: This research was funded by the Fundamental Research Grant Scheme (FRGS) of the Ministry of Higher Education Malaysia (grant number 203/PPSP / 6171209) and grants from Universiti Sains Malaysia (304.PPSP.6316338 and 304.PPSP.6316148).

Institutional Review Board Statement: Not applicable.

Informed Consent Statement: Not applicable.

Data Availability Statement: All data accessed and analyzed in this study are available in the article and its Supplementary Materials.

Acknowledgments: We would like to thank the Hamdan Tahir Library, Universiti Sains Malaysia, for helping to access some of the articles used in this work. A.A.I., E.N.S.E.A.R. and Y.W. are supported by the USM Fellowship Scheme. 
Conflicts of Interest: The authors declare no conflict of interest. The funders had no role in the design of the study; in the collection, analyses, or interpretation of data; in the writing of the manuscript, or in the decision to publish the results.

\section{References}

1. Wei, W.I.; Sham, J.S.T. Nasopharyngeal carcinoma. Lancet 2005, 365, 2041-2054. [CrossRef]

2. $\quad$ E A R, E.N.S.; Irekeola, A.A.; Yean Yean, C. Diagnostic and Prognostic Indications of Nasopharyngeal Carcinoma. Diagnostics 2020, 10, 611. [CrossRef]

3. AbuSalah, M.A.H.; Gan, S.H.; Al-Hatamleh, M.A.I.; Irekeola, A.A.; Shueb, R.H.; Yean Yean, C. Recent Advances in Diagnostic Approaches for Epstein-Barr Virus. Pathogens 2020, 9, 226. [CrossRef]

4. Jackson, C. Primary carcinoma of the nasopharynx. A table of cases. J. Am. Med. Assoc. 1901, XXXVII, 371-377. [CrossRef]

5. Digby, K.H.; Fook, W.L.; Che, Y.T. Nasopharyngeal carcinoma. BJS Br. J. Surg. 1941, 28, 517-537. [CrossRef]

6. Chang, E.T.; Adami, H.-O. The enigmatic epidemiology of nasopharyngeal carcinoma. Cancer Epidemiol. Biomark. Prev. 2006, 15, 1765-1777. [CrossRef] [PubMed]

7. Sireci, F.; Speciale, R.; Sorrentino, R.; Turri-Zanoni, M.; Nicolotti, M.; Canevari, F.R. Nasal packing in sphenopalatine artery bleeding: Therapeutic or harmful? Eur. Arch. Otorhinolaryngol. 2017, 274, 1501-1505. [CrossRef] [PubMed]

8. Chua, M.L.K.; Wee, J.T.S.; Hui, E.P.; Chan, A.T.C. Nasopharyngeal carcinoma. Lancet 2016, 387, 1012-1024. [CrossRef]

9. Wu, L.; Li, C.; Pan, L. Nasopharyngeal carcinoma: A review of current updates. Exp. Ther. Med. 2018, 15, 3687-3692. [CrossRef]

10. Toro, C.; Rinaldo, A.; Silver, C.E.; Politi, M.; Ferlito, A. Paraneoplastic syndromes in patients with nasopharyngeal cancer. Auris. Nasus. Larynx 2009, 36, 513-520. [CrossRef] [PubMed]

11. Chakroun, A.; Guigay, J.; Lusinchi, A.; Marandas, P.; Janot, F.; Hartl, D.M. Paraneoplastic dermatomyositis accompanying nasopharyngeal carcinoma: Diagnosis, treatment and prognosis. Eur. Ann. Otorhinolaryngol. Head Neck Dis. 2011, 128, 127-131. [CrossRef]

12. Wong, K.O. Dermatomyositis: A clinical of twenty-three cases in Hong Kong. Br. J. Dermatol. 1969, 81, 544-547. [CrossRef] [PubMed]

13. Bohan, A.; Peter, J.B. Polymyositis and dermatomyositis (second of two parts). N. Engl. J. Med. 1975, 292, 403-407. [CrossRef]

14. Huang, Y.L.; Chen, Y.J.; Lin, M.W.; Wu, C.Y.; Liu, P.C.; Chen, T.J.; Chen, Y.C.; Jih, J.S.; Chen, C.C.; Lee, D.D.; et al. Malignancies associated with dermatomyositis and polymyositis in Taiwan: A nationwide population-based study. Br. J. Dermatol. 2009, 161, 854-860. [CrossRef]

15. Chen, D.; Yuan, S.; Wu, X.; Li, H.; Qiu, Q.; Zhan, Z.; Ye, Y.; Lian, F.; Liang, L.; Xu, H.; et al. Incidence and predictive factors for malignancies with dermatomyositis: A cohort from southern China. Clin. Exp. Rheumatol. 2014, 32, 615-621.

16. Kuo, C.-F.; See, L.-C.; Yu, K.-H.; Chou, I.-J.; Chang, H.-C.; Chiou, M.-J.; Luo, S.-F. Incidence, cancer risk and mortality of dermatomyositis and polymyositis in Taiwan: A nationwide population study. Br. J. Dermatol. 2011, 165, 1273-1279. [CrossRef] [PubMed]

17. Leow, Y.H.; Goh, C.L. Malignancy in adult dermatomyositis. Int. J. Dermatol. 1997, 36, 904-907. [CrossRef] [PubMed]

18. Hu, W.; Chen, D.; Min, H. Study of 45 cases of nasopharyngeal carcinoma with dermatomyositis. Am. J. Clin. Oncol. 1996, 19, 35-38. [CrossRef] [PubMed]

19. Moher, D.; Liberati, A.; Tetzlaff, J.; Altman, D.G. Preferred reporting items for systematic reviews and meta-analyses: The PRISMA statement. BMJ 2009, 339, b2535. [CrossRef] [PubMed]

20. Munn, Z.; Moola, S.; Lisy, K.; Riitano, D.; Tufanaru, C. Methodological guidance for systematic reviews of observational epidemiological studies reporting prevalence and cumulative incidence data. Int. J. Evid. Based Healthc. 2015, 13, 147-153. [CrossRef]

21. Viechtbauer, W. Conducting meta-analyses in R with the metafor package. J. Stat. Softw. 2010, 36, 1-48. [CrossRef]

22. Egger, M.; Davey Smith, G.; Schneider, M.; Minder, C. Bias in meta-analysis detected by a simple, graphical test. BMJ 1997, 315, 629-634. [CrossRef] [PubMed]

23. Higgins, J.P.T.; Thompson, S.G. Quantifying heterogeneity in a meta-analysis. Stat. Med. 2002, 21, 1539-1558. [CrossRef]

24. Al-Ballaa, S.T.; Al-Dalaan, A.N.; El-Ramahi, K.M.; Al-Janadi, M.A.; Al-Shaikh, A.; Bahabri, S. Pattern of adult onset of polymyositis and dermatomyositis and association with malignancy. Ann. Saudi Med. 1993, 13, 525-529. [CrossRef] [PubMed]

25. Albayda, J.; Pinal-Fernandez, I.; Huang, W.; Parks, C.; Paik, J.; Casciola-Rosen, L.; Danoff, S.K.; Johnson, C.; ChristopherStine, L.; Mammen, A.L. Antinuclear Matrix Protein 2 Autoantibodies and Edema, Muscle Disease, and Malignancy Risk in Dermatomyositis Patients. Arthritis Care Res. 2017, 69, 1771-1776. [CrossRef]

26. Aljohani, G.; Bin Awad, E.A.; Alshahrani, K.; Alsaqar, M.M.; Albogami, B.; Almotywee, S.H.; Almaimouni, H.; Dirar, A.S.; Alrashid, A.; Rajendram, R.; et al. The prevalence, clinical features, predictive factors and investigations to screen for cancer in patients with inflammatory myositis A case series from two tertiary care centers in Riyadh, Saudi Arabia. Saudi Med. J. 2021, 42, 100-104. [CrossRef] [PubMed]

27. Amoura, Z.; Duhaut, P.; Huong, D.L.T.; Wechsler, B.; Costedoat-Chalumeau, N.; Francès, C.; Cacoub, P.; Papo, T.; Cormont, S.; Touitou, Y.; et al. Tumor antigen markers for the detection of solid cancers in inflammatory myopathies. Cancer Epidemiol. Biomarkers Prev. 2005, 14, 1279-1282. [CrossRef] 
28. András, C.; Ponyi, A.; Constantin, T.; Csiki, Z.; Szekanecz, E.; Szodoray, P.; Dankó, K. Dermatomyositis and polymyositis associated with malignancy: A 21-year retrospective study. J. Rheumatol. 2008, 35, 438-444. [PubMed]

29. András, C.; Bodoki, L.; Nagy-Vincze, M.; Griger, Z.; Csiki, E.; Dankó, K. Retrospective Analysis of Cancer-Associated Myositis Patients over the Past 3 Decades in a Hungarian Myositis Cohort. Pathol. Oncol. Res. 2020, 26, 1749-1755. [CrossRef] [PubMed]

30. Antiochos, B.B.; Brown, L.A.; Li, Z.; Tosteson, T.D.; Wortmann, R.L.; Rigby, W.F.C. Malignancy is associated with dermatomyositis but not polymyositis in Northern New England, USA. J. Rheumatol. 2009, 36, 2704-2710. [CrossRef]

31. Azuma, K.; Yamada, H.; Ohkubo, M.; Yamasaki, Y.; Yamasaki, M.; Mizushima, M.; Ozaki, S. Incidence and predictive factors for malignancies in 136 Japanese patients with dermatomyositis, polymyositis and clinically amyopathic dermatomyositis. Mod. Rheumatol. 2011, 21, 178-183. [CrossRef]

32. Benbassat, J.; Gefel, D.; Larholt, K.; Sukenik, S.; Morgenstern, V.; Zlotnick, A. Prognostic factors in polymyositis/dermatomyositis. A computer-assisted analysis of ninety-two cases. Arthritis Rheum. 1985, 28, 249-255. [CrossRef]

33. Bowerman, K.; Pearson, D.R.; Okawa, J.; Werth, V.P. Malignancy in dermatomyositis: A retrospective study of 201 patients seen at the University of Pennsylvania. J. Am. Acad. Dermatol. 2020, 83, 117-122. [CrossRef]

34. Callen, J.P.; Hyla, J.F.; Bole, G.G.J.; Kay, D.R. The relationship of dermatomyositis and polymyositis to internal malignancy. Arch. Dermatol. 1980, 116, 295-298. [CrossRef]

35. Cao, H.; Parikh, T.N.; Zheng, J. Amyopathic dermatomyositis or dermatomyositis-like skin disease: Retrospective review of 16 cases with amyopathic dermatomyositis. Clin. Rheumatol. 2009, 28, 979-984. [CrossRef]

36. Ceribelli, A.; Isailovic, N.; De Santis, M.; Generali, E.; Fredi, M.; Cavazzana, I.; Franceschini, F.; Cantarini, L.; Satoh, M.; Selmi, C. Myositis-specific autoantibodies and their association with malignancy in Italian patients with polymyositis and dermatomyositis. Clin. Rheumatol. 2017, 36, 469-475. [CrossRef]

37. Chang, L.; Zhang, L.; Jia, H.; Nie, Z.; Zhang, L. Malignancy in dermatomyositis: A retrospective paired case-control study of 202 patients from Central China. Medicine 2020, 99, e21733. [CrossRef]

38. Chan, H.L. Dermatomyositis and cancer in Singapore. Int. J. Dermatol. 1985, 24, 447-450. [CrossRef] [PubMed]

39. Chen, Y.-J.; Wu, C.-Y.; Huang, Y.-L.; Wang, C.-B.; Shen, J.-L.; Chang, Y.-T. Cancer risks of dermatomyositis and polymyositis: A nationwide cohort study in Taiwan. Arthritis Res. Ther. 2010, 12, R70. [CrossRef] [PubMed]

40. Chow, W.H.; Gridley, G.; Mellemkjaer, L.; McLaughlin, J.K.; Olsen, J.H.; Fraumeni, J.F.J. Cancer risk following polymyositis and dermatomyositis: A nationwide cohort study in Denmark. Cancer Causes Control 1995, 6, 9-13. [CrossRef] [PubMed]

41. Chuang, T.Y.; Lü, Y.C.; Deng, J.S.; Hsieh, T. Dermatomyositis and nasopharyngeal carcinoma. Taiwan Yi Xue Hui Za Zhi. 1974, 73, 365.

42. Ciudad-Blanco, C.; Avilés Izquierdo, J.A.; Campos-Domínguez, M.; Suárez-Fernández, R.; Lázaro Ochaita, P. Dermatomyositis: Assessment and Follow-up of 20 Patients. Actas Dermo Sifiliográficas 2011, 102, 448-455. [CrossRef] [PubMed]

43. Dani, L.; Ian Che, W.; Lundberg, I.E.; Hellgren, K.; Holmqvist, M. Overall and site-specific cancer before and after diagnosis of idiopathic inflammatory myopathies: A nationwide study 2002-2016. Semin. Arthritis Rheum. 2021, 51, 331-337. [CrossRef]

44. Dobloug, G.C.; Garen, T.; Brunborg, C.; Gran, J.T.; Molberg, Ø. Survival and cancer risk in an unselected and complete Norwegian idiopathic inflammatory myopathy cohort. Semin. Arthritis Rheum. 2015, 45, 301-308. [CrossRef]

45. El-Azhary, R.A.; Pakzad, S.Y. Amyopathic dermatomyositis: Retrospective review of 37 cases. J. Am. Acad. Dermatol. 2002, 46, 560-565. [CrossRef] [PubMed]

46. Fang, Y.-F.; Wu, Y.-J.J.; Kuo, C.-F.; Luo, S.-F.; Yu, K.-H. Malignancy in dermatomyositis and polymyositis: Analysis of 192 patients. Clin. Rheumatol. 2016, 35, 1977-1984. [CrossRef] [PubMed]

47. Fardet, L.; Dupuy, A.; Gain, M.; Kettaneh, A.; Chérin, P.; Bachelez, H.; Dubertret, L.; Lebbe, C.; Morel, P.; Rybojad, M. Factors associated with underlying malignancy in a retrospective cohort of 121 patients with dermatomyositis. Medicine 2009, 88, 91-97. [CrossRef]

48. Fujimoto, M.; Hamaguchi, Y.; Kaji, K.; Matsushita, T.; Ichimura, Y.; Kodera, M.; Ishiguro, N.; Ueda-Hayakawa, I.; Asano, Y.; Ogawa, F; et al. Myositis-specific anti-155/140 autoantibodies target transcription intermediary factor 1 family proteins. Arthritis Rheum. 2012, 64, 513-522. [CrossRef]

49. Hajialilo, M.; Ghorbanihaghjo, A.; Khabbazi, A.; Kolahi, S.; Jafari Nakhjavani, M.R.; Ebrahimi, A.A.; Zareh, H.; Malek Mahdavi, A. Long-term follow-up of 76 Iranian patients with idiopathic inflammatory myopathies. Int. J. Rheum. Dis. 2018, 21, 1627-1633. [CrossRef] [PubMed]

50. Hidano, A.; Kaneko, K.; Arai, Y.; Kikuchi, R. Survey of the prognosis for dermatomyositis, with special reference to its association with malignancy and pulmonary fibrosis. J. Dermatol. 1986, 13, 233-241. [CrossRef]

51. Higuchi, M.; Horiuchi, T.; Ishibashi, N.; Yoshizawa, S.; Niho, Y.; Nagasawa, K. Anticentromere antibody as a risk factor for cancer in patients with systemic sclerosis. Clin. Rheumatol. 2000, 19, 123-126. [CrossRef]

52. Hill, C.L.; Zhang, Y.; Sigurgeirsson, B.; Pukkala, E.; Mellemkjaer, L.; Airio, A.; Evans, S.R.; Felson, D.T. Frequency of specific cancer types in dermatomyositis and polymyositis: A population-based study. Lancet 2001, 357, 96-100. [CrossRef]

53. Hsu, J.-L.; Liao, M.-F.; Chu, C.-C.; Kuo, H.-C.; Lyu, R.-K.; Chang, H.-S.; Chen, C.-M.; Wu, Y.-R.; Chang, K.-H.; Weng, Y.-C.; et al. Reappraisal of the incidence, various types and risk factors of malignancies in patients with dermatomyositis and polymyositis in Taiwan. Sci. Rep. 2021, 11, 4545. [CrossRef]

54. Hunger, R.E.; Dürr, C.; Brand, C.U. Cutaneous leukocytoclastic vasculitis in dermatomyositis suggests malignancy. Dermatology 2001, 202, 123-126. [CrossRef] [PubMed] 
55. Ibañez, M.J.; Bolomo, G.; Gómez Sierra, M.S.; Miraglia, E.; Arena, G.; Chiavassa, A.M. Dermatomyositis: Presentation of 16 cases and review of the literature. Med. Cutan. Ibero-Lat. Am. 2016, 44, 110-122.

56. Ichimura, Y.; Matsushita, T.; Hamaguchi, Y.; Kaji, K.; Hasegawa, M.; Tanino, Y.; Inokoshi, Y.; Kawai, K.; Kanekura, T.; Habuchi, M.; et al. Anti-NXP2 autoantibodies in adult patients with idiopathic inflammatory myopathies: Possible association with malignancy. Ann. Rheum. Dis. 2012, 71, 710-713. [CrossRef] [PubMed]

57. Ikeda, N.; Takahashi, K.; Yamaguchi, Y.; Inasaka, M.; Kuwana, M.; Ikezawa, Z. Analysis of dermatomyositis-specific autoantibodies and clinical characteristics in Japanese patients. J. Dermatol. 2011, 38, 973-979. [CrossRef]

58. Ikeda, S.; Arita, M.; Misaki, K.; Mishima, S.; Takaiwa, T.; Nishiyama, A.; Ito, A.; Furuta, K.; Yokoyama, T.; Tokioka, F.; et al. Incidence and impact of interstitial lung disease and malignancy in patients with polymyositis, dermatomyositis, and clinically amyopathic dermatomyositis: A retrospective cohort study. Springerplus 2015, 4. [CrossRef] [PubMed]

59. Işık, M.; Bilgen, Ş.; Doğan, İ.; Kılıç, L. Inflammatory myopathies: One-center experience. Eur. J. Rheumatol. 2014, 1, 96-100. [CrossRef]

60. Kaji, K.; Fujimoto, M.; Hasegawa, M.; Kondo, M.; Saito, Y.; Komura, K.; Matsushita, T.; Orito, H.; Hamaguchi, Y.; Yanaba, K.; et al. Identification of a novel autoantibody reactive with 155 and $140 \mathrm{kDa}$ nuclear proteins in patients with dermatomyositis: An association with malignancy. Rheumatology 2007, 46, 25-28. [CrossRef] [PubMed]

61. Kang, E.H.; Lee, S.J.; Ascherman, D.P.; Lee, Y.J.; Lee, E.Y.; Lee, E.B.; Song, Y.W. Temporal relationship between cancer and myositis identifies two distinctive subgroups of cancers: Impact on cancer risk and survival in patients with myositis. Rheumatology 2016, 55, 1631-1641. [CrossRef]

62. Kannan, M.A.; Sundaram, C.; Uppin, M.; Mridula, R.; Jabeen, S.A.; Borgohain, R. Incidence of malignancies in biopsy-proven inflammatory myopathy. Neurol. India 2013, 61, 152-155. [CrossRef] [PubMed]

63. Koh, E.T.; Seow, A.; Ong, B.; Ratnagopal, P.; Tjia, H.; Chng, H.H. Adult onset polymyositis/dermatomyositis: Clinical and laboratory features and treatment response in 75 patients. Ann. Rheum. Dis. 1993, 52, 857-861. [CrossRef] [PubMed]

64. Kubo, M.; Ihn, H.; Yamane, K.; Kikuchi, K.; Yazawa, N.; Soma, Y.; Tamaki, K. Serum KL-6 in adult patients with polymyositis and dermatomyositis. Rheumatology 2000, 39, 632-636. [CrossRef]

65. Lakhanpal, S.; Bunch, T.W.; Ilstrup, D.M.; Melton, L.J. Polymyositis-Dermatomyositis and Malignant Lesions: Does an Association Exist? Mayo Clin. Proc. 1986, 61, 645-653. [CrossRef]

66. Lam, W.W.; Chan, H.; Chan, Y.L.; Fung, J.W.; So, N.M.; Metreweli, C. MR imaging in amyopathic dermatomyositis. Acta Radiol. 1999, 40, 69-72. [CrossRef] [PubMed]

67. Leatham, H.; Schadt, C.; Chisolm, S.; Fretwell, D.; Chung, L.; Callen, J.P.; Fiorentino, D. Evidence supports blind screening for internal malignancy in dermatomyositis: Data from 2 large US dermatology cohorts. Medicine 2018, 97, e9639. [CrossRef] [PubMed]

68. Lee, S.-W.; Jung, S.Y.; Park, M.-C.; Park, Y.-B.; Lee, S.-K. Malignancies in Korean patients with inflammatory myopathy. Yonsei Med. J. 2006, 47, 519-523. [CrossRef]

69. Li, X.; Tan, H. Value of (18)F-FDG PET/CT in the detection of occult malignancy in patients with dermatomyositis. Heliyon 2020, 6, e03707. [CrossRef] [PubMed]

70. Lim, C.H.; Tseng, C.-W.; Lin, C.-T.; Huang, W.-N.; Chen, Y.-H.; Chen, Y.-M.; Chen, D.-Y. The clinical application of tumor markers in the screening of malignancies and interstitial lung disease of dermatomyositis/polymyositis patients: A retrospective study. SAGE Open Med. 2018, 6, 2050312118781895. [CrossRef]

71. Liu, W.C.; Ho, M.; Koh, W.-P.; Tan, A.W.H.; Ng, P.P.L.; Chua, S.H.; Tan, S.H.; Tang, M.B.Y. An 11-year review of dermatomyositis in Asian patients. Ann. Acad. Med. Singap. 2010, 39, 843-847.

72. Liu, Y.; Xu, L.; Wu, H.; Zhao, N.; Tang, Y.; Li, X.; Liang, Y. Characteristics and predictors of malignancy in dermatomyositis: Analysis of 239 patients from northern China. Oncol. Lett. 2018, 16, 5960-5968. [CrossRef]

73. Maliha, P.G.; Hudson, M.; Abikhzer, G.; Singerman, J.; Probst, S. 18F-FDG PET/CT versus conventional investigations for cancer screening in autoimmune inflammatory myopathy in the era of novel myopathy classifications. Nucl. Med. Commun. 2019, 40, 377-382. [CrossRef] [PubMed]

74. Manchul, L.A.; Jin, A.; Pritchard, K.I.; Tenenbaum, J.; Boyd, N.F.; Lee, P.; Germanson, T.; Gordon, D.A. The frequency of malignant neoplasms in patients with polymyositis-dermatomyositis. A controlled study. Arch. Intern. Med. 1985, 145, 1835-1839. [CrossRef] [PubMed]

75. Maraví, T.Z.; Burgos, P.I.; Prieto-González, S. Clinical manifestations and antibody profile in 15 patients with dermatomyositis. Rev. Med. Chil. 2020, 148, 160-167. [CrossRef]

76. Marie, I.; Hatron, P.Y.; Levesque, H.; Hachulla, E.; Hellot, M.F.; Michon-Pasturel, U.; Courtois, H.; Devulder, B. Influence of age on characteristics of polymyositis and dermatomyositis in adults. Medicine 1999, 78, 139-147. [CrossRef] [PubMed]

77. Masiak, A.; Kulczycka, J.; Czuszyńska, Z.; Zdrojewski, Z. Clinical characteristics of patients with anti-TIF1- $\gamma$ antibodies. Reumatologia 2016, 54, 14-18. [CrossRef]

78. Mebazâa, A.; Boussen, H.; Nouira, R.; Rokbani, L.; Ben Osman-Dhahri, A.; Bouaouina, N.; Laouani-Kechrid, C.; Louzir, B.; Zahaf, A.; Kamoun, M.R. Dermatomyositis and malignancy in Tunisia: A multicenter national retrospective study of 20 cases. J. Am. Acad. Dermatol. 2003, 48, 530-534. [CrossRef]

79. Mercado, U.; Yocupicio, F.M.; Mercado, H. Dermatomyositis/polymyositis. Med. Interna Mex. 2020, 34, 502-508. [CrossRef] 
80. Mimura, Y.; Yazawa, N.; Tamaki, Z.; Ashida, R.; Jinnin, M.; Asano, Y.; Tada, Y.; Kubo, M.; Ihn, H.; Tamaki, K. Anti-p53 antibodies in patients with dermatomyositis/polymyositis. Clin. Rheumatol. 2007, 26, 1328-1331. [CrossRef]

81. Mustafa, K.N.; Al-Heresh, A.M.; Khataybeh, O.Y.; Alawneh, K.M.; Khader, Y.S. Low prevalence of malignancy in patients with idiopathic inflammatory myopathies in Jordan. Clin. Exp. Rheumatol. 2015, 33, 731-733.

82. Mustafa, K.N.; Dahbour, S.S. Clinical characteristics and outcomes of patients with idiopathic inflammatory myopathies from Jordan 1996-2009. Clin. Rheumatol. 2010, 29, 1381-1385. [CrossRef]

83. Naesström, M.; Kakol, M.; Kamkar, V.; Baranska-Rybak, W.; Sokolowska-Wojdylo, M.; Stawczyk, M.; Nowicki, R. A rarity that can lead to a casualty-A retrospective study of 12 cases of dermatomyositis. Br. J. Med. Pract. 2015, 8, a822.

84. Ogawa-Momohara, M.; Muro, Y.; Mitsuma, T.; Katayama, M.; Yanaba, K.; Nara, M.; Kakeda, M.; Kono, M.; Akiyama, M. Strong correlation between cancer progression and anti-transcription intermediary factor $1 \gamma$ antibodies in dermatomyositis patients. Clin. Exp. Rheumatol. 2018, 36, 990-995. [PubMed]

85. Ohnmar; Tun, Z.P.; Nyunt, C.C.; Htay, S.L.; Oo, S.L.; Lwin, C.M.; Soe, Y.M.; Soe, C.; Thit, W.M. Profile of various idiopathic inflammatory myopathies at two university hospitals in Yangon, Myanmar. Neurol. Asia 2020, 25, $285-291$.

86. Peng, J.-C.; Sheen, T.-S.; Hsu, M.-M. Nasopharyngeal carcinoma with dermatomyositis: Analysis of 12 cases. Arch. Otolaryngol. Neck Surg. 1995, 121, 1298-1301. [CrossRef] [PubMed]

87. Requena, C.; Alfaro, A.; Traves, V.; Nagore, E.; Llombart, B.; Serra, C.; Martorell, A.; Guillén, C.; Sanmartín, O. Dermatomiositis paraneoplásica: Estudio de 12 casos. Actas Dermosifiliogr. 2014, 105, 675-682. [CrossRef] [PubMed]

88. Rose, C.; Hatron, P.Y.; Brouillard, M.; Hachulla, E.; Gosset, D.; Marlier, C.; Piette, F.; Devulder, B. Predictive signs of cancers in dermatomyositis. Study of 29 cases. Rev. Med. Interne 1994, 15, 19-24. [CrossRef]

89. Sato, J.D.O.; Sallum, A.M.E.; Ferriani, V.P.L.; Marini, R.; Sacchetti, S.B.; Okuda, E.M.; De Carvalho, J.F.; Pereira, R.M.R.; Len, C.A.; Terreri, M.T.R.A.; et al. A Brazilian registry of juvenile dermatomyositis: Onset features and classification of 189 cases. Clin. Exp. Rheumatol. 2009, 27, 1031-1038.

90. Sellami, K.; Mseddi, M.; Snoussi, M.; Gharbi, H.; Frikha, F.; Salah, R.B.; Jallouli, M.; Marzouk, S.; Masmoudi, A.; Bahloul, Z.; et al. Malignancy in a retrospective cohort of 17 patients with Dermatomyositis or Polymyositis in southern Tunisia. Rom. J. Intern. Med. 2018, 56, 243-249. [CrossRef]

91. Selva-O'Callaghan, A.; Grau, J.M.; Gámez-Cenzano, C.; Vidaller-Palacín, A.; Martínez-Gómez, X.; Trallero-Araguás, E.; AndíaNavarro, E.; Vilardell-Tarrés, M. Conventional Cancer Screening versus PET/CT in Dermatomyositis/Polymyositis. Am. J. Med. 2010, 123, 558-562. [CrossRef] [PubMed]

92. Shimizu, K.; Kobayashi, T.; Kano, M.; Hamaguchi, Y.; Takehara, K.; Matsushita, T. Anti-transcriptional intermediary factor 1- $\gamma$ antibody as a biomarker in patients with dermatomyositis. J. Dermatol. 2020, 47, 64-68. [CrossRef] [PubMed]

93. De Souza, F.H.C.; Barros, T.B.M.; Levy-Neto, M.; Shinjo, S.K. Adult dermatomyositis: Experience of a Brazilian tertiary care center. Rev. Bras. Reumatol. 2012, 52, 897-902.

94. Sparsa, A.; Liozon, E.; Herrmann, F.; Ly, K.; Lebrun, V.; Soria, P.; Loustaud-Ratti, V.; Bouyssou-Gauthier, M.-L.; Boulinguez, S.; Bédane, C.; et al. Routine vs extensive malignancy search for adult dermatomyositis and polymyositis: A study of 40 patients. Arch. Dermatol. 2002, 138, 885-890. [CrossRef]

95. Stockton, D.; Doherty, V.R.; Brewster, D.H. Risk of cancer in patients with dermatomyositis or polymyositis, and follow-up implications: A Scottish population-based cohort study. Br. J. Cancer 2001, 85, 41-45. [CrossRef] [PubMed]

96. Tang, M.M.; Thevarajah, S. Paraneoplastic Dermatomyositis: A 12-year Retrospective Review in the Department of Dermatology Hospital Kuala Lumpur. Med. J. Malays. 2010, 65, 138-142.

97. Tani, K.; Tomioka, R.; Sato, K.; Furukawa, C.; Nakajima, T.; Toyota, Y.; Shimizu, T.; Nakayama, M.; Miyata, J.; Kishi, J.; et al. Comparison of clinical course of polymyositis and dermatomyositis: A follow-up study in Tokushima University Hospital. $J$. Med. Investig. 2007, 54, 295-302. [CrossRef] [PubMed]

98. Tembe, A.G.; Ramteke, S.; Joshi, V.R.; Balakrishnan, C. Dermatomyositis/polymyositis associated with malignancy: Our experience with ten patients and review of relevant literature. Int. J. Rheum. Dis. 2008, 11, 269-273. [CrossRef]

99. Teoh, J.W.; Yunus, R.M.; Hassan, F.; Ghazali, N.; Abidin, Z.A.Z. Nasopharyngeal carcinoma in dermatomyositis patients: A 10-year retrospective review in Hospital Selayang, Malaysia. Rep. Pract. Oncol. Radiother. 2014, 19, 332-336. [CrossRef]

100. Teh, C.L.; Wong, J.S.; Soo, H.H. Polymyositis and dermatomyositis in Sarawak: A profile of patients treated in the Sarawak general hospital. Rheumatol. Int. 2012, 32, 265-268. [CrossRef]

101. Tong, M. A review of dermatomyositis cases at Hospital Besar Kuala Lumpur 1989-1993. Med. J. Malays. 1995, $50,32-36$.

102. Trallero-Araguás, E.; Labrador-Horrillo, M.; Selva-O'Callaghan, A.; Martínez, M.A.; Martínez-Gómez, X.; Palou, E.; RodriguezSanchez, J.L.; Vilardell-Tarrés, M. Cancer-associated myositis and anti-p155 autoantibody in a series of 85 patients with idiopathic inflammatory myopathy. Medicine 2010, 89, 47-52. [CrossRef]

103. Trallero-Araguás, E.; Grau-Junyent, J.M.; Labirua-Iturburu, A.; García-Hernández, F.J.; Monteagudo-Jiménez, M.; FraileRodriguez, G.; Les-Bujanda, I.; Rodriguez-Carballeira, M.; Sáez-Comet, L.; Selva-O'Callaghan, A. Clinical manifestations and long-term outcome of anti-Jo1 antisynthetase patients in a large cohort of Spanish patients from the GEAS-IIM group. Semin. Arthritis Rheum. 2016, 46, 225-231. [CrossRef] [PubMed]

104. Travassos, A.R.; Borges-Costa, J.; Filipe, P.; Marques, M.S. Malignancy associated with dermatomyositis-A retrospective single-center study with 33 patients. Acta Reum. Port. 2013, 38, 92-97. 
105. Tripathi, R.; Fernandez, A.P. Characteristics of hospitalized dermatomyositis patients with underlying malignancy: A nationally representative retrospective cohort study. Arch. Dermatol. Res. 2020. [CrossRef] [PubMed]

106. Troyanov, Y.; Targoff, I.N.; Payette, M.-P.; Raynauld, J.-P.; Chartier, S.; Goulet, J.-R.; Bourré-Tessier, J.; Rich, E.; Grodzicky, T.; Fritzler, M.J.; et al. Redefining dermatomyositis: A description of new diagnostic criteria that differentiate pure dermatomyositis from overlap myositis with dermatomyositis features. Medicine 2014, 93, 318-332. [CrossRef] [PubMed]

107. Ueda-Hayakawa, I.; Hamaguchi, Y.; Okiyama, N.; Motegi, S.; Yamaoka, T.; Miyake, S.; Higashi, A.; Okamoto, H.; Takehara, K.; Fujimoto, M. Autoantibody to transcriptional intermediary factor- $1 \beta$ as a myositis-specific antibody: Clinical correlation with clinically amyopathic dermatomyositis or dermatomyositis with mild myopathy. Br. J. Dermatol. 2019, 180, 881-887. [CrossRef]

108. Ueki, M.; Kobayashi, I.; Takezaki, S.; Tozawa, Y.; Okura, Y.; Yamada, M.; Kuwana, M.; Ariga, T. Myositis-specific autoantibodies in Japanese patients with juvenile idiopathic inflammatory myopathies. Mod. Rheumatol. 2019, 29, 351-356. [CrossRef] [PubMed]

109. Uthman, I.; Vázquez-Abad, D.; Senécal, J.-L. Distinctive features of idiopathic inflammatory myopathies in French Canadians. Semin. Arthritis Rheum. 1996, 26, 447-458. [CrossRef]

110. Van de Vlekkert, J.; Hoogendijk, J.E.; de Visser, M. Long-term follow-up of 62 patients with myositis. J. Neurol. 2014, 261, 992-998. [CrossRef]

111. Wakata, N.; Kurihara, T.; Saito, E.; Kinoshita, M. Polymyositis and dermatomyositis associated with malignancy: A 30-year retrospective study. Int. J. Dermatol. 2002, 41, 729-734. [CrossRef]

112. Yosipovitch, G.; Tan, A.; LoSicco, K.; Manabat, C.G.; Kannagra, A.; Carroll, C.; Chan, Y.H.; Ng, P.; Jorizzo, J. A comparative study of clinical characteristics, work-up, treatment, and association to malignancy in dermatomyositis between two tertiary skin centers in the USA and Singapore. Int. J. Dermatol. 2012, 52, 813-819. [CrossRef]

113. Zhang, W.; Jiang, S.-P.; Huang, L. Dermatomyositis and malignancy: A retrospective study of 115 cases. Eur. Rev. Med. Pharmacol. Sci. 2009, 13, 77-80.

114. Stertz, G. Polymyositis. Berl. Klin. Wochenschr. 1916, 53, 489.

115. Zahr, Z.A.; Baer, A.N. Malignancy in myositis. Curr. Rheumatol. Rep. 2011, 13, 208-215. [CrossRef]

116. Chen, Y.J.; Wu, C.Y.; Shen, J.L. Predicting factors of malignancy in dermatomyositis and polymyositis: A case-control study. Br. J. Dermatol. 2001, 144, 825-831. [CrossRef] [PubMed]

117. Botsios, C.; Boscolo Rizzo, P.; Da Mosto, M.C.; Ostuni, P.; Sfriso, P.; Todesco, S.; Marchiori, C. Rhinopharyngeal carcinoma and dermatomyositis: Description of a clinical case. Reumatismo 2002, 54, 48-51. [PubMed]

118. Mitra, A.; Ahmed, S.; Stables, G. Dermatomyositis associated with nasopharyngeal carcinoma in a Caucasian patient: The first report in the United Kingdom P705. J. Am. Acad. Dermatol. 2006, 54, AB78. [CrossRef]

119. Boussen, H.; Mebazaa, A.; Gritli, S.; Khalfallah, S.; Touati, S.; El May, A.; Benna, F.; Ayed, B.; Nouira, R.; Bouaouina, N. Dermatomyositis and nasopharyngeal carcinoma: 3 cases. Ann. Dermatol. Venereol. 2000, 127, 389-392. [PubMed]

120. Boussen, H.; Mebazaa, A.; Nasr, C.; Khalfallah, S.; Gamoudi, A.; Mezlini, A.; Ladgham, A. Dermatomyositis and nasopharyngeal carcinoma: Report of 8 cases. Arch. Dermatol. 2006, 142, 109-116. [CrossRef] [PubMed]

121. Boussetta, N.; Dhahri, R.; Metoui, L.; Ariba, Y.B.; Gharsallah, I. Dermatomyositis Revealing Nasopharyngeal Carcinoma. Rheumatology 2015, 5, 1149-2161. [CrossRef]

122. Ezejiofor, O.I.; Ozor, A.G.; Okpala, C.I.; Enechukwu, N.A.; Nwankwo, H.M. Dermatomyositis in a patient with nasopharyngeal carcinoma. Niger. J. Surg. Sci. 2015, 25, 32. [CrossRef]

123. Patel, S.C.; Paulino, A.C.; Johnston, D.; Wiederhold, L.; Castillo, R.; Venkatramani, R. Gemcitabine-induced radiation recall myositis in a patient with relapsed nasopharyngeal carcinoma. Pract. Radiat. Oncol. 2017, 7, e19-e22. [CrossRef]

124. Bica, B.; França, C.T.; Vargas, A.B. Juvenile dermatomyositis associated to lymphoepithelioma, a nasopharyngeal carcinoma. Pediatr. Rheumatol. 2011, 9, 1. [CrossRef]

125. Low, Q.J.; Hon, S.A.; Garry Siow, P.W.; Lim, T.H.; Lee, R.A.; Tan, Y.A.; Cheo, S.W. Dermatomyositis and nasopharyngeal carcinoma. QJM An Int. J. Med. 2020, 113, 753-754. [CrossRef]

126. Kabuto, M.; Fujimoto, N.; Teramura, K.; Tateishi, M.; Hamaguchi, Y.; Fujimoto, M.; Tanaka, T. A case of dermatomyositis with esophageal fistula in whom blind mucosal biopsy detected occult oropharyngeal carcinoma. Case Rep. Dermatol. 2014, 6, 268-273. [CrossRef]

127. Vardy, J.; Wong, E.; Izard, M.; Clifford, A.; Clarke, S.J. Life-threatening anaphylactoid reaction to amifostine used with concurrent chemoradiotherapy for nasopharyngeal cancer in a patient with dermatomyositis: A case report with literature review. Anticancer Drugs 2002, 13, 327-330. [CrossRef] [PubMed]

128. Ferris, R.L.; Koch, W.M. Connective tissue disease coincident with nasopharyngeal carcinoma: Two sporadic cases in a Western population. Arch. Otolaryngol. Head Neck Surg. 2003, 129, 101-105. [CrossRef] [PubMed]

129. Feldman, D.; Hochberg, M.C.; Zizic, T.M.; Stevens, M.B. Cutaneous vasculitis in adult polymyositis/dermatomyositis. J. Rheumatol. 1983, 10, 85-89.

130. Basset-Seguin, N.; Roujeau, J.C.; Gherardi, R.; Guillaume, J.C.; Revuz, J.; Touraine, R. Prognostic factors and predictive signs of malignancy in adult dermatomyositis. A study of 32 cases. Arch. Dermatol. 1990, 126, 633-637. [CrossRef]

131. Ponyi, A.; Constantin, T.; Garami, M.; Andras, C.; Tallai, B.; Vancsa, A.; Gergely, L.; Danko, K. Cancer-Associated Myositis: Clinical Features and Prognostic Signs. Ann. N. Y. Acad. Sci. 2005, 1051, 64-71. [CrossRef] [PubMed]

132. So, M.W.; Koo, B.S.; Kim, Y.-G.; Lee, C.-K.; Yoo, B. Idiopathic inflammatory myopathy associated with malignancy: A retrospective cohort of 151 Korean patients with dermatomyositis and polymyositis. J. Rheumatol. 2011, 38, 2432-2435. [CrossRef] [PubMed] 
133. Sigurgeirsson, B.; Lindelöf, B.; Edhag, O.; Allander, E. Risk of cancer in patients with dermatomyositis or polymyositis. A population-based study. N. Engl. J. Med. 1992, 326, 363-367. [CrossRef] [PubMed]

134. Marie, I.; Hachulla, E.; Hatron, P.Y.; Hellot, M.F.; Levesque, H.; Devulder, B.; Courtois, H. Polymyositis and dermatomyositis: Short term and longterm outcome, and predictive factors of prognosis. J. Rheumatol. 2001, 28, 2230-2237. [CrossRef]

135. Pautas, E.; Chérin, P.; Piette, J.C.; Pelletier, S.; Wechsler, B.; Cabane, J.; Herson, S. Features of polymyositis and dermatomyositis in the elderly: A case-control study. Clin. Exp. Rheumatol. 2000, 18, 241-244.

136. Huber, A.; Feldman, B.M. Long-term outcomes in juvenile dermatomyositis: How did we get here and where are we going? Curr. Rheumatol. Rep. 2005, 7, 441-446. [CrossRef] 